\title{
MIĘDZY REKLAMĄ A NAZWĄ WŁASNĄ. PRZYMIOTNIK TANI W NAZWACH POLSKICH APTEK
}

Słowa tematyczne: chrematonimia, motywacja nazw, nazwy aptek, reklama, Prawo farmaceutyczne

\section{WPROWADZENIE}

Wyrazy tani, tańszy, tanio, najtaniej, taniej itp. to słowa klucze w marketingu, używane masowo w sloganach reklamowych, w nazwach akcji promocyjnych i programów lojalnościowych, np. Tania sobota w Lidlu, Tani i tańszy, Taniej ksiązki w Stokrotce, Tanie Stany, Kupuj Taniej. Odpowiednią sugestię zawierają też nazwy firm typu Firma Handlowa Tani But, Firma Handlowo-Ustugowo-Produkcyjna Tani Opat, STP Szybko Tanio Pysznie, Najtaniej w Toruniu S.C. Marzeniem klienta jest kupić tanio, a intencją sprzedawcy jest przyciągnięcie klienta poprzez zapewnienia, że nie zapłaci dużo za towar czy usługi. Reguła ta sprawdza się przynajmniej w polskim marketingu ${ }^{1}$.

Motywacja nazw firm typu Tanie Zabawki czy Centrum Tanich Leków, Tania Apteka wydaje się tak samo przejrzysta. Jednak ten popularny przymiotnik w nazwach polskich aptek stanowi szczególny przypadek, pokazujący jak płynna, niedookreślona jest granica pomiędzy nazwami własnymi a wyrazami pospolitymi. Analiza chrematonimów z członem tani $(-a,-e)$ stanowi też przyczynek do dyskusji, czym są nazwy własne i jakie funkcje pełnią te znaki językowe, dla których zgodnie z teorią ważniejszy jest zakres (wyznaczanie) niż treść.

Omówiony w niniejszym artykule materiał dowodzi, że onomastyka, a zwłaszcza chrematonomastyka nieustannie napotyka nowe problemy badawcze, których dostarcza zmieniająca się rzeczywistość. Inspiracją do zajęcia się

1 Jak zauważa W. Cockiewicz, porównując polski i niemiecki obraz świata na przykładzie niemieckiego billig i polskiego tani, ,ten pierwszy eksponuje w swojej strukturze semantycznej komponent 'niskiej jakości', podczas gdy drugi podkreśla składnik 'korzystny przy zakupie' (...) polski slogan reklamowy Wszystko i tanio byłby na tle niemieckiego JOS wręcz antyreklamą" (Cockiewicz, 2018, s. 10). 
tym tematem stało się uliczne ogłoszenie z napisem uszeregowanym w trzech liniach: APTEKA na Francuskiej. TANIE LEKI. NAZWA WLASNA (fot. 1). Można zakładać, że zapisany dużo mniejszą od reszty czcionką termin nazwa własna nie przyciąga uwagi większości przechodniów. Dla potencjalnych klientów apteki ważniejsza jest strzałka pokazująca kierunek i odległość $50 \mathrm{~m}$. Onomasta natomiast postawi pytanie: czemu służy ten dopisek? Jaki jest sens podawania informacji, której na szyldach, ogłoszeniach nigdy się nie umieszcza? Odpowiedź, która jest jednym z celów artykułu, pokazuje, że motywacja w onomastyce - nawet jeżeli z pozoru wydaje się przejrzysta - może zaskakiwać, a związana bywa z przyczynami, które wychodzą poza schemat motywacji charakterystyczny dla danej grupy onimów.

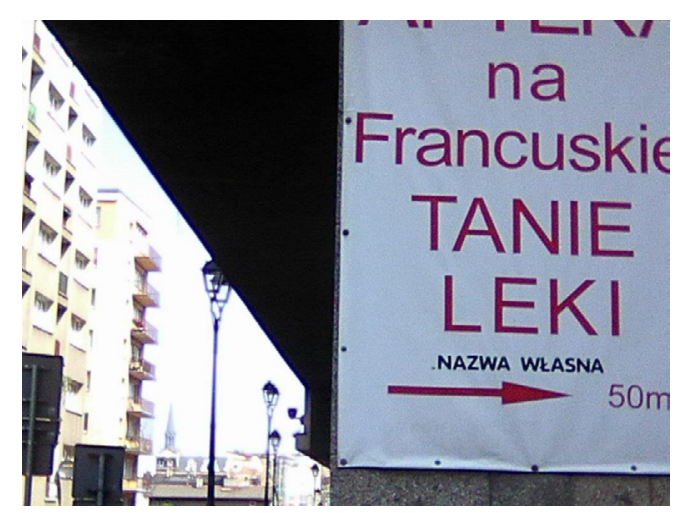

Fot. 1. TANIE LEKI. Nazwa własna

\section{NAZWY APTEK W BADANIACH ONOMASTYCZNYCH}

O motywacji semantycznej w nazwach aptek - m.in. Poznania, Krakowa, Bydgoszczy, Lublina - pisały: M. Rutkiewicz-Hanczewska (2000, 2003), H. Górny (2003), Ł.M. Szewczyk (2003), M. Pabiś (2006), I. Seiffert (2005, 2006, 2008), A. Czapla i A. Kutyła (2012). Część z tych prac ogranicza się do materiału współczesnego, część omawia nazwy także w perspektywie diachronicznej. Historią nazw aptek zajmowali się również historycy farmacji². Ten typ onimów wyróżniają na tle innych mianowania tradycyjne, pochodzące od godła apteki. Pozostałe to m.in. nazwy topograficzne (lokalizujące) lub dzierżawcze, wskazujące na właściciela. Duża liczba onimów zawiera semantyczne odniesienia do sfery zdrowia, specyfików leczniczych, roślin tradycyjnie używanych w medy-

2 Dokładny stan badań z zakresu historii farmacji przedstawiają prace M. Rutkiewicz (2000) i M. Pabiś (2006). 
cynie ludowej, postaci mitologicznych. Charakterystyczne dla nowszej warstwy nazewniczej są złożenia z członami łacińskiego pochodzenia vita, pharm/farm itp.

W niniejszej pracy uznajemy nazwy aptek za chrematonimy. Przedmiotem analizy są bowiem onimy z członem o wyraźnej funkcji marketingowej: tani $(-a,-e)$. O ich motywacji decyduje niewątpliwie przynależność aptek do grupy obiektów funkcjonujących w przestrzeni gospodarczej, a więc za A. Gałkowskim (2011) przyporządkujemy je do chrematonimii marketingowej. W latach 90. XX w. znacząco rozwinął się rynek farmaceutyczny w Polsce. Niektóre placówki upadają, łączą się, zmieniają właścicieli, powstają nowe. Branża aptekarska podlega prawom ekonomii, co na przykładzie Wrocławia stwierdza I. Seiffert, podkreślając, że upodobnienie się aptek do „zwykłych” firm handlowych znajduje odzwierciedlenie również w nazewnictwie (Seiffert, 2008, s. 213). Stanowią one część krajobrazu lingwistycznego miasta, uzasadnione jest więc ich uwzględnianie w opracowaniach dotyczących nazewnictwa miejskiego i lokalnych obiektów handlowych (Siwiec, 2012, s. 173-202). Podobnie jak nazwy sklepów, nazwy aptek bywają elementem dyskusji o granicy pomiędzy chrematonimią i urbanonimią czy toponimią (Szewczyk, 2003, s. 145-146; Górny, 2007; Świtała-Cheda, 2011, s. 473). Niniejszy artykuł nie ma na celu rozstrzygnięcia, czy apteki to przedmiot badań jednego czy drugiego działu onomastyki. Ważne wydaje się spostrzeżenie A. Myszki, że nazwy obiektów handlowych analizuje się zarówno jako chrematonimy, jak i toponimy w zależności od celu badań (Myszka, 2016, s. 50-52).

Uwzględniając fakt, że apteka jest placówką ochrony zdrowia, nazewnictwo aptek można również włączyć w nurt badań onomastycznych związanych z funkcjonowaniem nazw własnych w medycynie i ochronie zdrowia. Badania te dotyczą głównie nazw leków i suplementów diety, zwanych też farmakonimami (Rutkiewicz-Hanczewska, 2007; Tomasik, 2013, 2016). Zwraca uwagę marketingowe podejście do produktów leczniczych, które traktowane są jak inne produkty handlowe, i temu też podporządkowane jest kreowanie nowych nazw. Zdaniem S. Tomasik (2013, s. 257) rozwój rynku farmaceutycznego i funkcjonującego na nim nazewnictwa wynika z faktu „komercjalizacji choroby”. M. Rutkiewicz-Hanczewska zauważa, że struktura nazw oddziałuje zarówno na emocjonalne, jak i racjonalne elementy wyboru, którymi zwykle kieruje się klient. Dla leków tworzy się zarówno nazwy abstrakcyjne, jak i transparentne, sugerujące pewne treści (np. szybkość, intensywność działania). Dzieje się tak pomimo zaleceń nadzoru farmaceutycznego i instytucji rejestrujących leki, mówiących, iż nazwy nie powinny przekazywać żadnych treści reklamowych ani perswazyjnych (Rutkiewicz-Hanczewska, 2007, s. 202-203; Tomasik 2013, s. 258259). Owo „przemycanie” treści można uznać niekiedy za element manipula- 
cji, zwłaszcza w wypadku nazw suplementów diety. Zebrany przez S. Tomasik materiał pokazuje, że nazwy te pod względem struktury przypominają z jednej strony nazwy innych produktów spożywczych, z drugiej strony — nazwy leków, sugerują więc działanie terapeutyczne produktów leczniczych, chociaż w odróżnieniu od tamtych nie przechodzą szczegółowych badań klinicznych (Tomasik, 2016, s. 312). O komercjalizacji w ochronie zdrowia mówi również artykuł K. Banderowicz (2011) poświęcony nazwom polskich sanatoriów, w którym autorka zwraca uwagę na funkcję perswazyjną i reklamową tych onimów. I nazwy obiektów, i nazwy produktów medycznych to nazwy handlowe, chrematonimy o funkcji marketingowej, ale - co ważne - używane w sferze ,wrażliwej” etycznie, bo dotyczącej ludzkiego życia i zdrowia. Faktem jest, że działalność aptekarza wiąże się z balansowaniem między poczuciem odpowiedzialności, służbą społeczną a biznesową koniecznością utrzymania się na rynku.

\section{DZIAŁALNOŚĆ APTEK — REGULACJE PRAWNE}

Warto zwrócić uwagę, że w świadomości potocznej samo pojęcie apteka wpisuje się w pole semantyczne HANDEL. Sprzedaż leków jest działalnością handlową, a same leki są towarem. Definicje słownikowe mówią, że apteka to: „,sklep, w którym sprzedaje się lekarstwa i środki opatrunkowe” (WSJP), ,sklep, w którym się sprzedaje leki, środki opatrunkowe, artykuły sanitarne" (SJP PWN). Jednakże takie powszechne przekonanie kłóci się ze specjalistycznym, branżowym wizerunkiem apteki, o który dba samorząd zawodowy. „Apteka to nie sklep z lekami" - przypomina jeden z nagłówków na stronie internetowej Naczelnej Izby Aptekarskiej (Nowelizacja 2017). Swoboda działalności gospodarczej w przypadku handlu lekami jest ograniczana przez odpowiednie przepisy. Obecnie w Polsce reguluje ją przede wszystkim ustawa z dnia 6 września 2001 r. Prawo farmaceutyczne (Dz.U. z 2001 r., nr 126, poz. 1381). Według ustawy apteka ma ściśle określoną funkcję:

Art. 86.1. Apteka jest placówką ochrony zdrowia publicznego, w której osoby uprawnione świadczą w szczególności usługi farmaceutyczne, o których mowa w ust. 2.

2. Nazwa apteka zastrzeżona jest wyłącznie dla miejsca świadczenia usług farmaceutycznych obejmujących:

1) wydawanie produktów leczniczych i wyrobów medycznych, określonych w odrębnych przepisach;

2) sporządzanie leków recepturowych, w terminie nie dłuższym niż 48 godzin od złożenia recepty przez pacjenta, a w przypadku recepty na lek recepturowy zawierający środki odurzające lub oznaczonej ,wydać natychmiast” — w ciągu 4 godzin;

3) sporządzenie leków aptecznych;

4) udzielanie informacji o produktach leczniczych i wyrobach medycznych. 
W ustawowej definicji apteki, co warto podkreślić, nie padają wyrazy sprzedaż, sprzedawać. Oferta handlowa w postaci suplementów diety czy dermokosmetyków jest dodatkową działalnością apteki.

Apteki są nadzorowane przez Głównego Inspektora Farmaceutycznego i wojewódzkich inspektorów farmaceutycznych, którzy wydają przedsiębiorcom zezwolenia na prowadzenie aptek ogólnodostępnych. Ważną funkcję pełni też wspomniany samorząd aptekarski - czyli Naczelna Izba Aptekarska oraz okręgowe izby aptekarskie. Potwierdza on między innymi kwalifikacje do wykonywania zawodu farmaceuty, a także opiniuje projekty przepisów dotyczących farmacji. Trzeba podkreślić, że od średniowiecza wyrób i sprzedaż leków jest działalnością koncesjonowaną, zmienia się charakter koncesji i instytucje, które wydają odpowiednie pozwolenia.

Co ważne, podobnie jak w przypadku innego rodzaju działalności handlowo-usługowej, nie ma obowiązku nadawania aptece nazwy. Jest to jedynie zwyczaj. Nie istnieją też tutaj żadne szczegółowe regulacje i wytyczne dla przedsiębiorców. Placówki są identyfikowane przez nadzór farmaceutyczny na podstawie indywidualnego numeru. Nazwę apteki — jeśli jest — podaje się jednak we wniosku o udzielenie zezwolenia na jej prowadzenie. Najczęściej różni się ona od nazwy firmy, która występuje z tym wnioskiem do inspektora farmaceutycznego.

\section{STRUKTURA NAZW Z CZŁONEM TANI}

Wszystkie apteki, które uzyskały zezwolenie na prowadzenie działalności, są wymienione w internetowym Rejestrze Aptek. Według danych na dzień 14.12.2018 zarejestrowane były w nim 16304 apteki. Wśród nich 86 nosi interesujące nas nazwy z członem przymiotnikowym tani $(-a,-e)$. Wszystkie one zawierają sugestię, że apteka ma atrakcyjny cenowo asortyment, np.: Centrum Tanich Leków (48 aptek) oraz Tanie Leki (11), Super Tanie Leki (2), Tylko Tanie Leki. Używa się również wyrażeń tania apteka, tanie leczenie (np. Apteka-Nova „Centrum Taniego Leczenia"). W nazwach nie stosuje się stopnia wyższego przymiotnika. Tylko jeden chrematonim zawiera przymiotnik w stopniu najwyższym $(A P-$ TEKA GLÓWNA - NAJTAŃSZA APTEKA W REGIONIE ${ }^{3}$ ). Dwie inne apteki noszą nazwę z pokrewnym przysłówkiem (Apteka Vademecum Blisko i tanio! oraz Apteka Vademecum, Blisko i tanio!). Łącznie jest to 58 różnych wielowyrazowych zestawień. Formy te niejednokrotnie powtarzają się, co niekoniecznie

3 Formy nazw podano zgodnie z Rejestrem Aptek. Nazwy w Rejestrze nie mają ujednoliconej pisowni wielkich i małych liter, kapitalików oraz interpunkcji. Zapis taki nie musi być identyczny z pisownią stosowaną na szyldzie, w dokumentach urzędowych lub w innych źródłach. 
oznacza, że właścicielem placówki jest ta sama firma. Wynika to raczej z mody nazewniczej. Apteki mające w nazwie najbardziej popularne w rejestrze zestawienie centrum tanich leków należą do kilkunastu różnych właścicieli. Ten schemat nazw znajdziemy głównie w południowej Polsce, w województwach: małopolskim (24) oraz śląskim (18), a więc można tu mówić o lokalnym powielaniu pewnego wzoru, z modnym w chrematonimii członem głównym centrum (tak jak np. Centrum Pożyczek, Centrum Urody, Centrum Druku).

Warto przyjrzeć się strukturze takich chrematonimów. Niektóre — jak widać powyżej - są rozbudowane, składają się z dwóch niezależnych członów. Jednowyrazowy chrematonim Tania to pojedynczy przykład w spisie. Mało jest też zestawień dwu-, trójwyrazowych. Są to: TANIA APTEKA / Tania Apteka (3)4, APTEKA TANIA / Apteka Tania (3), TANIE LEKI (2), APTEKA - TANIE LEKI, Apteka Tanich leków [tak!], CENTRUM TANIEGO LEKU, TANIA APTEKA RODZINNA, TANIE APTEKI RODZINNE (2), Supertania Apteka Łęczycka. Oprócz zgodnej z zasadami pisowni formy supertania zarejestrowano również nazwy SUPER TANIA APTEKA PRZYJAZNA oraz Super Tania Apteka Panax. W materiale znajduje się również nazwa nawiązująca do adresu internetowego SuperTaniaApteka.pl ${ }^{5}$.

Inną budowę ma trójwyrazowa nazwa SYRENKA TANIE LEKI, którą noszą 2 apteki w województwie mazowieckim ${ }^{6}$. Nie jest to typowe zestawienie. Chrematonim ma dwa niepowiązane składniowo człony. I to jest właśnie struktura wyróżniająca nazwy aptek z przymiotnikiem tani. Zawierają one jeden człon, którego motywacja semantyczna jest na ogół typowa dla tego rodzaju placówek. Możemy to stwierdzić, porównując je z materiałem $\mathrm{z}$ innych prac onomastycznych. Motywują te formy m.in.: toponimy, zwłaszcza nazwy ulic (Na Francuskiej, Na Różanej, Majakowskiego, Hallera, Wieniecka, Andrychowska, Przy Skarbówce), słownictwo łacińskie i nazewnictwo mitologiczne (Eliksir, NovaVita, Hygieia, Vademecum), słownictwo metaforyczne sugerujące dobrą obsługę (CALOTYGODNIOWA APTEKA FAMILIJNA, SUPERAPTEKA, APTEKA BLI$S K O$ CIEBIE). Przymiotnik tani w różnej postaci pojawia się częściej w drugim członie niż w pierwszym.

Przy użyciu wyrażeń typu tanie leki, tania apteka powstał zbiór długich, wieloczłonowych - i przez to mało użytecznych w codziennej komunikacji chrematonimów: Rogatka Warszawska TANIE LEKI, Apteka Duży Berlin Cen-

\footnotetext{
4 W nawiasach podano liczbę takich identycznych chrematonimów.

5 Apteka ta ma zezwolenie na prowadzenie sprzedaży internetowej, ale jej adres supertaniaapteka.pl nie działa (stan na 14.12.2018).

6 Do spółki, która jest właścicielem tej apteki, należy jeszcze kilka innych aptek. W większości nazywają się one Syrenka (8), jedna ma w nazwie drugi człon, wskazujący na lokalizację (Syrenka Przy (sic) Szpitalu).
} 
trum Tanich Leków, Apteka Max Trzebińskie Centrum Tanich Leków, Apteka Nowa Farmacja Centrum Tanich Leków, Apteka Przy (sic) Samolocie Centrum Tanich Leków Marta Piskorz, Apteka 4 PORY ROKU Zabrzańskie Centrum Tanich Leków, CALOTYGODNIOWA APTEKA FAMILIJNA - TYLKO TANIE LEKI, Super Tania Apteka im. Zawiszy Czarnego ${ }^{7}$, CENTRUM TANICH LE$K O ́ W-A P T E K A S ́ S$. BARBARY. Gdybyśmy nie wiedzieli, że jest to w całości nazwa własna, moglibyśmy uznać, że widzimy nazwę apteki i połączony z nią krótki slogan reklamowy, czyli komunikat o funkcji marketingowej, z jakimi stykamy się na co dzień w handlu (np. Biedronka - codziennie niskie ceny, Media Markt — nie dla idiotów, Lidl. Więcej na radość z życia!, Smyk - cały dla małych). Wiemy jednak, że jest to nomen proprium — znalazło się ono bowiem w odpowiedniej rubryce zatytułowanej „nazwa”, wpisane przez przedsiębiorcę we wniosku o rejestrację apteki (lub w modyfikacji zgłoszenia) i w takiej postaci podaje ją oficjalny Rejestr Aptek. Akt nominacji został zatem potwierdzony urzędowo przez inspektora farmaceutycznego wydającego zezwolenie i status nazwy własnej nie powinien budzić wątpliwości.

\section{NAZEWNICTWO A ZAKAZ REKLAMY APTEK}

Przegląd dokumentów, opinii i komentarzy publikowanych przez izby aptekarskie na stronach internetowych prowadzi do wniosku, że pojawienie się tego rodzaju wieloczłonowych chrematonimów wiąże się z uchwaleniem artykułu 94a Prawa farmaceutycznego, który zawiera następujący punkt, obowiązujący od 1 stycznia 2012 r. ${ }^{8}$, „Zabroniona jest reklama aptek i punktów aptecznych oraz ich działalności. Nie stanowi reklamy informacja o lokalizacji i godzinach pracy apteki lub punktu aptecznego". Użycie w nazwie apteki jako wyrazów fundujących prostego połączenia apelatywnego tanie leki pozwala ominąc zakaz reklamy, ponieważ napis taki - jako element nazwy - umieszcza się na każdym ogłoszeniu, ulotce, plakacie informującym, gdzie znajdziemy aptekę. Można przypuszczać, że w większości przypadków drugi człon został dodany do wcześniejszej nazwy apteki. Na przykład wspomniana wyżej Rogatka Warszawska to nazwa apteki w Lublinie wymieniona w pracy A. Czapli i A. Kutyły (2012) jeszcze w postaci jednoczłonowej.

Na nieprzestrzeganie, a właściwie omijanie zakazu reklamy zwracają uwagę Naczelna Izba Aptekarska oraz okręgowe izby aptekarskie, ale największe kompetencje mają wojewódzcy inspektorzy farmaceutyczni, którzy wydają

7 Zawisza Czarny jest patronem ulicy, przy której mieści się placówka.

8 Punkt ten został zmieniony przez ustawę z 12 maja 2011 r. o refundacji leków, środków spożywczych specjalnego przeznaczenia żywieniowego oraz wyrobów medycznych (Dz.U. z 2011 r., nr 122, poz. 696). 
zezwolenia na prowadzenie aptek, a jednocześnie czuwają nad przestrzeganiem odpowiednich przepisów, w tym nad przestrzeganiem zakazu reklamy. Właściciel może się odwołać od ich decyzji do Głównego Inspektora Farmaceutycznego. Część spraw pomiędzy GIF a przedsiębiorcami znajduje finał w Wojewódzkim Sądzie Administracyjnym, a w następnej instancji — w Naczelnym Sądzie Administracyjnym. Do końca roku 2018 w Centralnej Bazie Orzeczeń Sądów Administracyjnych opublikowano 32 orzeczenia, które odnoszą się bezpośrednio lub pośrednio do wykorzystania wyrażeń typu tanie leki, niskie ceny, ceny hurtowe $\mathrm{w}$ nazwie lub $\mathrm{w}$ niedozwolonej reklamie. Najstarsze $\mathrm{z}$ nich pochodzi z 2008 r., ale większość ukazała się po 2012 roku, czyli po wejściu w życie wspomnianego artykułu 94a ustawy. Orzeczenia sądu dotyczą różnych przypadków, nie tylko odmowy zezwolenia na prowadzenie apteki ze względu na problematyczną nazwę, ale także formy graficznej szyldu, ulotki reklamowej, stoiska itp., które „nieodpowiednio” eksponują część chrematonimu (tanie leki, niskie ceny, ceny hurtowe, supercena) ${ }^{9}$. Można powiedzieć, używając sformułowania M. Rutkowskiego, że nie są to nazwy „czyste” pod względem prawnym, chociaż proces kreowania chrematonimów teoretycznie wiąże się z koniecznością sprawdzenia legalności nazwy (Rutkowski, 2003, s. 242-243).

W uzasadnieniach do wyroków zwraca się uwagę, powołując się niejednokrotnie na wcześniejsze orzeczenia, że dla klienta status nazwy własnej jest drugorzędny, a problematyczne wyrażenia odbierze on prawdopodobnie jak każdy inny komunikat marketingowy:

W ocenie Sądu słuszne jest stanowisko, w którym twierdzi się, że przeciętny odbiorca komunikatu (widniejącego na szybie, plakacie, standzie, ulotce, folderze, w oknie itd.) nie będzie odróżniał statusu zwrotów: „tanie leki”, ,super cena”, ,wysokie rabaty”, ,ceny hurtowe”, ,promocja", itd. (VI SA/Wa 2357/16, wyrok WSA w Warszawie z 24.03.2017, zob. też VI SA/Wa 2129/16, wyrok WSA w Warszawie z 5.04.2017)

W ramach zakazu reklamy apteki nie jest dopuszczalne takie graficzne przedstawienie nazwy apteki, które same w sobie nie zawierając elementów ocennych ani zachęcających do zakupu, mogą jednak zostać przyjęte przez ich odbiorców jako zachęta do kupna. (VI SA/Wa 2875/15, wyrok WSA w Warszawie z 14.07.2016) ${ }^{10}$

\section{ORZECZNICTWO SĄDÓW ADMINISTRACYJNYCH NA TLE TEORII NAZW WŁASNYCH}

W uzasadnieniach do orzeczeń sądowych dotyczących prowadzenia aptek i hurtowni farmaceutycznych znajdujemy interesujący również dla onomasty ma-

9 Sprawy dotyczą też wyrazów pospolitych tanie / tańsze oraz leki wyróżnianych w ulotkach informacyjnych inną czcionką (np. „Zgodnie z ustawą refundacyjną APTEKA ma obowiązek wydawania TAŃSZYCH odpowiedników LEKÓW").

${ }^{10} \mathrm{~W}$ cytowanych orzeczeniach została zachowana oryginalna pisownia. 
teriał, który zarówno pozwala obserwować praktykę nominacji, jak i nasuwa spostrzeżenia z zakresu teorii nazw własnych. Sprawy sądowe dotykają kwestii teoretycznych: czym jest nazwa własna, czym różni się od wyrazu pospolitego i jaka jest jej funkcja. Zdaniem inspektorów farmaceutycznych, a także sędziów, nazwa może być reklamą, zwłaszcza kiedy eksponuje się ją w szczególny sposób - np. odpowiednią czcionką - na ulotkach i szyldach. Stanowisko to odpowiada ustaleniom chrematonomastyki - nazwy pełnią funkcję perswazyjną właściwą reklamie. Chrematonimy są minimalnymi komunikatami wywołującymi pożądane skojarzenia. W pracach onomastycznych padają niejednokrotnie stwierdzenia, które warto tu przypomnieć: nazwy własne stanowią „mentalną kotwę, która zatrzymuje uwagę kupującego" (Rutkowski, 2003, s. 253), jest to „rodzaj streszczenia, skrótu, dzięki któremu myśl odbiorcy podąża w ściśle określonym kierunku” (Rutkiewicz-Hanczewska, 2017, s. 413), „,nazwa firmy lub produktu jest elementem sine qua non rozbudowanego przekazu reklamowego, ale i sama w sobie może być używana lub odbierana w kategoriach reklamowych" (Gałkowski, 2014, s. 65).

$\mathrm{Z}$ treści orzeczeń sądowych, które w uzasadnieniu przytaczają obszernie argumentację obu stron, wynika, że występujący jako strona przedsiębiorcy starają się marginalizować marketingowy charakter nazewnictwa. Uznanie, że pewna konkretna nazwa jest reklamą, określono nawet w jednym z pozwów jako „całkowicie chybione"11. Argumentację podawaną przez właścicieli aptek cechuje zbieżność z podstawowym, ale dyskutowanym szeroko w onomastyce twierdzeniem, że propria mają przede wszystkim funkcję identyfikacyjną, powinny „W sposób stały i skrótowy zidentyfikować obiekt, a nie charakteryzować go" (Jakus-Borkowa, 1987, s. 10), ,[i]ch rola w języku ogranicza się do wskazywania (oznaczania, wyznaczania) bez przekazywania treści znaczeniowej" (Kaleta, 2005, s. 18). Na te cechy nazw wskazuje między innymi spółka skarżąca decyzję Głównego Inspektora Farmaceutycznego w sprawie niezgodnej z przepisami reklamy apteki:

Wyjaśniła [spółka], że nazwą apteki, ujawnioną w zezwoleniu, jest „[...] Tanie Leki”, a zatem jej zawarcie w treści spornej ulotki miało charakter wyłącznie informacyjny. Nadto stwierdziła, że ogólne pojęcie reklamy odróżnia zachętę do zakupu określonych towarów od zwrócenia uwagi na określoną placówkę handlowa [tak!], a taki właśnie cel przysługuje wskazanej ulotce. Podkreśliła, że sama nazwa apteki, czy wskazanie jej lokalizacji, nie sugeruje klientom korzyści, jakie mogą odnieść dokonując zakupu produktów w danej aptece. Aby konkretne działanie mogło zostać uznane za reklamę, winno cechować się zamiarem wywołania określonej reakcji u potencjalnych klientów, zaś nazwa apteki, mająca charakter indywidualizujący dany podmiot, czy jej lokalizacja, nie stanowi takowej zachęty. (VI SA/Wa 1740/14, wyrok WSA w Warszawie z 28.11.2014)

${ }^{11}$ Zob. VI SA/Wa 4319/14, wyrok WSA w Warszawie z 5.05.2015. 
Nazwy aptek zostały uznane - jak wynika z powyższego pisma — za toponimy, nazwy lokalizujące, a nie za chrematonimy. Polemizując z tą argumentacją, przedkładającą funkcję identyfikacyjną nad perswazję, i w tym przypadku moglibyśmy odwołać się do literatury onomastycznej, powracając też częściowo do wspomnianej we wstępie dyskusji o granicy pomiędzy toponimią a chrematonimią. Funkcja lokalizująca wykreowanej nazwy wysuwa się na pierwszy plan, kiedy nazwany obiekt wrośnie w lokalny krajobraz. Ale nie na tym skupia się przedsiębiorca. Pierwotnie onim służy przyciągnięciu uwagi klienta, a nie orientacji w terenie. M. Graf zwróciła uwagę na tę ewolucję funkcji, biorąc za przykład nazwy nowych inwestycji mieszkaniowych: „Nazwy te - niczym etykieta towaru - początkowo pełnią funkcję reklamową (perswazyjną); później dopiero, gdy stają się komponentem przestrzeni miejskiej - funkcję identyfikacyjną, która z czasem nabiera charakteru funkcji dominującej” (Graf, 2015, s. 54). W tym samym celu tworzy się nazwy aptek.

Dowody mające potwierdzać, że dane proprium nie jest reklamą, są rozmaite i mogą zaciekawić językoznawcę. Interesujące jest na przykład uzasadnienie odnoszące się do stopniowania form przymiotnikowych:

W ocenie skarżącej gdyby zamierzała używać w nazwie przymiotnika „najtańsze”, czy też wyrażenia „tańsze niż w innych aptekach" lub innego znaczeniowo równoważnego, wówczas można by uznać, iż nazwa rzeczywiście pełni funkcję niedozwolonej reklamy, gdyż posługuje się stopniowanym przymiotnikiem, wskazującym (jednoznacznie sugerującym) klientom, iż apteka oferuje leki tańsze niż we wszystkich innych aptekach na danym (relewantnym) rynku. Przymiotnik ,tanie" jest w tym kontekście neutralny i wolny od charakterystycznej dla reklamy sugestywności. W żaden sposób nie można go rozumieć jako oznaczającego leki tańsze niż w innych aptekach. (VI SA/Wa 4319/14, wyrok WSA w Warszawie z 5.05.2015).

Po lekturze powyższego fragmentu nasuwa się przypuszczenie, że unika się w nazwach aptek stopnia wyższego, aby nie przywoływać skojarzeń z reklamą, w której typowym zabiegiem jest porównywanie. Inną ciekawostkę onomastyczną stanowi tłumaczenie jednego z właścicieli apteki - przytoczone tu nie za orzeczeniem sądowym, lecz za prasą (Kowalska, 2017) - iż nazwa, którą nadał, pochodzi od zdrobnienia imienia żony (Tania). Brzmi ono anegdotycznie, ale ze względu na homonimię przymiotnika i zdrobnienia imienia obie motywacje należy uznać za prawdopodobne.

\section{UWAGI KOŃCOWE}

Podsumowując skrótowy przegląd orzeczeń sądowych, trzeba zaznaczyć, iż chociaż argumentacja obu stron sporu o nazwy z członem tani $(-a,-e)$ nawiązuje $\mathrm{w}$ dużym stopniu do teorii nazw własnych, terminologia onomastyczna w ogóle nie pojawia się $\mathrm{w}$ analizowanym orzecznictwie. $\mathrm{W}$ wyrokach dotyczących nazw 
aptek nie przytacza się też odpowiedniej literatury naukowej. W uzasadnieniu sąd posługuje się jedynie definicją reklamy ze słownika wyrazów obcych pod red. M. Bańki: „działanie mające na celu zachęcenie potencjalnych klientów do zakupu konkretnych towarów lub do skorzystania z określonych usług" (WSWO, 2003).

Mimo iż w uzasadnieniach wyroków przyznaje się, że interesujące nas wyrażenie może stanowić element niedozwolonej reklamy, sądy niejednokrotnie rozstrzygają spory na korzyść firmy prowadzącej aptekę, a nie inspektora farmaceutycznego. Zwraca się bowiem uwagę, że inspektor farmaceutyczny nie może zabronić używania pełnej nazwy przez aptekę, jeżeli wydał wcześniej zgodę na jej działalność. Udzielając zezwolenia, zaakceptował również nazwę — jest ona podawana przez przedsiębiorcę w odpowiednim wniosku razem z innymi danymi. Zabronienie używania formy, którą wcześniej zarejestrowano, podważałoby m.in. zasadę zaufania do państwa.

Wspomniany na początku artykułu napis „nazwa własna” umieszczony na ogłoszeniu ma stanowić zabezpieczenie przed zarzutami niedozwolonej reklamy. Akt nominacji formalnie zawiesza związek z apelatywną bazą (,nazwa nie znaczy, a oznacza”), a jednocześnie — jak można zakładać — twórcy tego rodzaju chrematonimów liczą na dosłowne odczytanie komunikatu tanie leki, ponieważ granica pomiędzy określeniami apelatywnymi a propriami jest płynna. Jest to dość szczególna motywacja nazewnicza, uwarunkowana ograniczeniami, jakim podlega farmaceutyczna działalność handlowa.

\section{LITERATURA}

Banderowicz, K. (2011). Mens sana in corpore sano. Współczesne tendencje w nazewnictwie polskich sanatoriów [Mens sana in corpore sano. Contemporary Tendencies in the Naming of Polish Sanatorium]. W: M. Biolik, J. Duma (red.). Chrematonimia jako fenomen współczesności [Chrematonymy as a Phenomenon of Modern Times] (s. 43-58). Olsztyn: Wydawnictwo UWM.

Cockiewicz, W. (2018). O językowym obrazie świata - niekognitywnie, a może tylko kognitywnie inaczej [On Linguistic Picture of the World - Non-cognitively, or Perhaps Only in Another Cognitive Way]. Polonica, XXXVIII, s. 1-14, http://dx.doi.org/10.17651/POLON.38.1.

Czapla, A., Kutyła, A. (2012). Nazwy lubelskich aptek [Names of Lublin-based Pharmacies]. Roczniki Humanistyczne KUL, LX, z. 6, s. 75-85.

Gałkowski, A. (2011). Chrematonimy w funkcji kulturowo-użytkowej. Onomastyczne studium porównawcze na materiale polskim, włoskim i francuskim [Chrematonyms in the Cultural-functional Context. An Onomastic Comparative Study Based on Polish, Italian and French Resources]. Wyd. 2. Łódź: Wyd. UŁ.

Gałkowski, A. (2014). Motywacja w procesie tworzenia chrematonimii marketingowej [Motivation in the Process of the Creation of Marketing Chrematonymy]. W: M. Graf (red.). Przestrzenie językoznawstwa. Prace dedykowane profesor Irenie Sarnowskiej-Giefing [Spaces of Linguistics. Papers Dedicated to Prof. Irena Sarnowska-Giefing]. Poznańskie Spotkania Językoznawcze, 27, s. 63-72, http://dx.doi.org/10.14746/psj.2014.XXVII.5. 
Górny, H. (2003). Tendencje onimiczne w nazwach krakowskich aptek [Onymic Tendencies in the Pharmacy Names in Kraków]. Acta onomastica, XLIV, s. 15-28.

Górny, H. (2007). Uwagi do artykułu M. Pabiś „Nazwy krakowskich aptek” [About Article M. Pabiś „Nazwy krakowskich aptek” (Pharmacies' Names in Cracow)]. Język Polski, LXXXVII, z. 2, s. 166.

Graf, M. (2015). Onimy marketingowe - między informacją a perswazją [Marketing onyms - between information and persuasion]. LingVaria, X, 1 (19), s. 49-59, http://dx.doi.org/10.12797/LV.10.2015.19.03.

Jakus-Borkowa, E. (1987). Nazewnictwo polskie [Polish Proper Names]. Opole: Wyd. WSP.

Kaleta, Z. (2005). Teoria nazw własnych [Theory of Proper Names]. W: E. Rzetelska-Feleszko (red.). Polskie nazwy własne. Encyklopedia [Polish Proper Names. Encyclopaedia] (s. 15-36). Warszawa-Kraków: TNW - IJP PAN.

Kowalska, K. (2017). Apteki nie można reklamować nazwą firmy [Pharmacies Cannot Be Advertised with Company Name]. Rzeczpospolita, 5.06.2017, www.rp.pl (dostęp: 1 IV 2019).

Myszka, A. (2016). Urbanonimia Rzeszowa. Językowo-kulturowy obraz miasta [The Urbanonymy of Rzeszów. Lingua-cultural View of the City]. Rzeszów: Wyd. UR.

Pabiś, M. (2006). Nazwy krakowskich aptek [Pharmacies' Names in Cracow]. Język Polski, LXXXVI, z. 5, s. 376-388.

Rutkiewicz, M. (2000). Semantyka nazw poznańskich aptek [Meanings of the Names of Pharmacies in Poznań]. Język Polski, LXXX, z. 3-4, s. 185-196.

Rutkiewicz-Hanczewska, M. (2003). Nazwy wiedeńskich aptek — schemat nazewniczy czy specyfikacja miejsca [The Names of Pharmacies in Vienna - Naming Convention or Sense of the Place]. Onomastica Slavogermanica, XXIV, s. 173-181.

Rutkiewicz-Hanczewska, M. (2007). Farmakonimy jako narzędzie brandingu [Farmaconyms as an Instrument of Branding]. Język Polski, LXXXVII, z. 3, s. 199-211.

Rutkiewicz-Hanczewska, M. (2017). Dyfuzja semantyczna w proprialnej przestrzeni marketingowej, czyli rodzime nazwy odapelatywne w modzie [Semantic Diffusion in the Proprial Marketing Space, or Trends in the Use of Native Appellative Names]. Onomastica, LXI/2, s. 413429, http://dx.doi.org/10.17651/ONOMAST.61.2.30.

Rutkowski, M. (2003). Nazwy na sprzedaż. O nazewnictwie na usługach marketingu [Names for Sale. On Onomastics for Marketing]. Onomastica, XLVIII, s. 239-254.

Seiffert, I. (2005). Nazwy wrocławskich aptek — przeszłość i współczesność [The Names of Pharmacies in Wrocław. The Past and the Present]. W: R. Łobodzińska (red.). Z najnowszych tendencji w polskim nazewnictwie [The Latest Trends in Polish Proper Names] (s. 83-98). Lask: Oficyna Wydawnicza „Leksem”.

Seiffert, I. (2006). Dawne nazwy górnośląskich aptek [The Historical Names of Pharmacies in Upper Silesia]. Rozprawy Komisji Językowej WrTN, XXXIII, s. 25-31.

Seiffert, I. (2008). Dolnośląskie apteki i ich nazwy w przekroju historycznym [Pharmacies in Lower Silesia - Their Names in Historical Depictions]. Onomastica Slavogermanica, XXVII, s. 207-233.

Siwiec, A. (2012). Nazwy własne obiektów handlowo-usługowych w przestrzeni miasta [The Names of Retail and Service Facilities in the Urban Space]. Lublin: Wyd. UMCS.

Szewczyk, Ł.M. (2003). Nazwy aptek w regionie kujawsko-pomorskim [The Names of Pharmacies in Kujawsko-Pomorskie Region]. W: M. Święcicka (red.). Polszczyzna bydgoszczan. Historia i współczesność [Polish Language of Bydgoszcz. History and Contemporary Times] (s. 145154). Bydgoszcz: Wyd. Akademii Bydgoskiej.

Świtała-Cheda, M. (2011). W sprawie terminologii nazw firm i ich miejsca w chrematonimii [On the Terminology of Business Names and Their Place in Chrematonymy]. W: M. Biolik, J. Duma (red.). Chrematonimia jako fenomen współczesności [Chrematonymy as a Phenomenon of Modern Times] (s. 469-475). Olsztyn: Wyd. UWM. 
Tomasik, S. (2013). Onomastyka w służbie zdrowiu, czyli o nazwach handlowych leków. Rekonesans badawczy [Onomastics in the Service of Health, or About the Drugs Trade Names. Reconnaissance Research]. Acta onomastica, LIV, s. 256-271.

Tomasik, S. (2016). Onomastyka w służbie zdrowiu, czyli o nazwach handlowych suplementów diety. Rekonesans badawczy [Onomastics in the Service of Health, or About the Dietary Supplements Names. Reconnaissance Research]. Acta onomastica, LV, s. 305-314.

WSWO (2003): M. Bańko (red.). Wielki słownik wyrazów obcych [The Great Dictionary of Loanwords]. Warszawa: Wydawnictwo Naukowe PWN.

\title{
ŹRÓDŁA INTERNETOWE
}

Centralna Baza Orzeczeń Sądów Administracyjnych, http://orzeczenia.nsa.gov.pl (dostęp: 3 I 2019).

Lubelska Okręgowa Izba Aptekarska, https://www.loia.pl (dostęp: 14 V 2018).

Nowelizacja ustawy 2017: Nowelizacja ustawy - Prawo farmaceutyczne (tzw. „Apteka dla Aptekarza"), https://www.nia.org.pl/2017/06/26/nowelizacja-ustawy-prawo-farmaceutycznetzw-apteka-dla-aptekarza/ (dostęp: 2 I 2019).

Rejestr Aptek: Krajowy Rejestr Zezwoleń na Prowadzenie Aptek Ogólnodostępnych, Punktów Aptecznych oraz Rejestr Udzielonych Zgód na Prowadzenie Aptek Szpitalnych i Zakładowych, https://rejestrymedyczne.csioz.gov.pl (dostęp: 14 XII 2018).

SJP PWN: Słownik Języka Polskiego PWN, https://sjp.pwn.pl (dostęp: 19 XII 2018).

Śląska Izba Aptekarska, https://www.katowice.oia.pl/ (dostęp: 14 V 2018).

WSJP: Wielki Słownik Języka Polskiego, www.wsjp.pl (dostęp: 19 XII 2018).

\author{
SUMMARY \\ BETWEEN AN ADVERTISEMENT AND A PROPER NAME. \\ THE ADJECTIVE TANI 'CHEAP' IN THE NAMES OF POLISH PHARMACIES
}

The paper considers a particular case of onomastic motivation, providing examples of the use of the adjective tani 'cheap' in the creation of pharmacy names in Poland (e.g. Tanie Leki 'cheap medicines', Tania Apteka 'cheap pharmacy'). This Polish word is frequently used in marketing, both as an element of company names and marketing slogans. In many instances tani constitutes part of a complex pharmacy name, e.g.: Całotygodniowa Apteka Familijna - Tylko Tanie Leki, Super Tania Apteka im. Zawiszy Czarnego, Centrum Tanich Leków - Apteka św. Barbary. On the basis of judgments from Polish administrative courts, the article discusses the question of the distinction or lack of one between advertisements and proper names. The significant fact is that the Pharmaceutical Law has prohibited the advertising of the operations of pharmacies since 2012 and, as a result, the use of names with the component tani was found to be in violation of the provision. In response to this, the owners of stores have argued that the proper name refers to the object alone, having no literal meaning. The controversial phrases were used to create legal names which are placed on signboards and in announcements. The paper focuses on a more general problem: chrematonyms and appellative lexis can hardly be distinguished due to their persuasive and marketing value.

Keywords: chrematonymy, onomastic motivation, pharmacy names, advertisement, the Pharmaceutical Law 